\title{
Impact of COVID-19 on Real Estate Industry with Reference to India
}

\author{
Jyoti Bhoj
}

\begin{abstract}
The recent pandemic has affect economies of various countries and India is no exception. The IMF projected Indian growth rate at 1.9 percent for the financial year 2021which was previous estimated at 5.8 percent. This possess a great threat for Indian economy. This effect of COVID-19 will be felt across sectors. Indian real estate which was already recovering from the aftermath of demonetization and various reforms was jolted by this pandemic with lockdown construction activity has stopped, real estate sales are not happening. The Indian real estate should prepare itself to brace for a post COVID-19 world and should prepare itself to utilise various new and tech driven steps to come back on track. This article deals with understanding the pre pandemic real estate industry and analysing the impact of COVID-19 on Indian real estate industry. It also presents the threats and opportunities available to different real estate market participant.
\end{abstract} EMI

Keywords: COVID-19, R.E, Registration act, REITs, InvITs,

\section{INTRODUCTION}

According to Section 2(6) of the Registration Act, 1908, "Immovable Property includes land, building, hereditary allowances, rights to ways, lights, ferries, fisheries or any other benefit to arise out of land, and things attached to the earth or permanently fastened to anything which is attached to the earth but not standing timber, growing crops nor grass". The real estate transaction embraces: Purchase, Sale and Development of land (both residential and nonresidential buildings).There are various benefits of real estate investment. For example it provides you with better and secured returns, it has a high tangible value, an investor can earn periodic return in form of rent income plus it has tax benefits. Real estate segment makes huge commitment to Indian GDP with it contributing nearly 6\%. In average yearly house value index has seen a development pace of $2.8 \%, .5 \%, 4.3 \%, 8.4 \%, 2.3 \%$ and $3 \%$ from 2010 to 2015 . India normal yearly lodging record development rate were $8.9 \%, 11.1 \%, 8.5 \%, 3.4 \%, 6.7 \%$ and $3.9 \%$ from 2010 to 2015. The general accessible supply of office land was diminished possibly to the tune of 2.2 million sq $\mathrm{ft}$ from 2.7 million sq $\mathrm{ft}$ in 2013. Real estate market is expected to grow by 2040 to Rs 65,000 crore (US\$ 9.30 billion) from Rs 12,000 crore (US\$ 1.72 billion) in 2019. India's real estate part is anticipated to reach USD 180 billion by 2020 from USD 126 billion out of 2015, as per a joint report by CREDAI and JLL. Real estate in India is assessed to arrive at a market size of US\$ 1 trillion by 2030 from US $\$ 120$ billion out of 2017 and contribute 13 percent of the nation's GDP by 2025.

Revised Manuscript Received on May 15, 2020.

* Correspondence Author

Jyoti Bhoj*, Research Scholar, University of Rajasthan, Jaipur.

(C) The Authors. Published by Blue Eyes Intelligence Engineering and Sciences Publication (BEIESP). This is an open access article under the CC BY-NC-ND license (http://creativecommons.org/licenses/by-nc-nd/4.0/)
Retail, commercial and hospitality real estate business are additionally developing impressively, giving the truly necessary framework to India's developing needs. Segments, for example, IT, retail, counselling and web based business have enrolled appeal for office space lately. The Indian real estate sector has observed high growth in recent times and there is a rise in demand for office as well as residential spaces. Private Equity and Venture Capital investments in this sector reached to US\$ 1.47 billion between Jan-Mar 2019.India has performed genuinely well as far as yearly development in house value record for the year 2010 to 2015. Where nations like USA not just registers low yearly normal development than India in 2010, 2011, 2012 and 2014 in certain years it was additionally negative. In the event that we take a gander at Hong Kong it has performed genuinely well period 2010 to 2015. In all the years it has enlisted a positive yearly development rate. On the off chance that we take a gander at china in 2011 it enlisted $2.1 \%$, in 2014 - 4.5\% and in 2015 just $0.4 \%$ of yearly normal development. Canada's development rate ranges from 3.1 to $6.5 \%$. UK for the period 2010 to 2015 seethed from $-1.1 \%$ to $8.3 \%$. In the event that we see India average yearly development rate it stayed positive for the period extending from 2011 to 2015 the least it was in 2013 3.4\% and the most noteworthy it was in 2011 11.1\%. India among the seven nations is just beneath Hong Kong. Its normal yearly development rate is for the period 2011 to 2015 is $6.72 \%$. In average yearly house price index has seen a development pace of $2.8 \%, .5 \%, 4.3 \%, 8.4 \%, 2.3 \%$ and $3 \%$ from 2010 to 2015. India average yearly housing file development rate were $8.9 \%, 11.1 \%, 8.5 \%, 3.4 \%, 6.7 \%$ and $3.9 \%$ from 2010 to 2015 individually. India yearly house value file with the exception of 2013 has stayed higher than the yearly normal house record development rate. The position of India was regarding appreciation in housing prices as the housing rates developed by just $0.6 \%$ year-onyear ascend during July-September (quarter 2) throughout the year-back period on slow demand. In the primary quarter from April-June quarter of 2019, India remained at eleventh situation with a $7.7 \%$ year-on-year ascend in home prices. However slow deals, high stock and absence of liquidity with developers were the components that confined the ascent in house price. Guidelines forced by the government to guarantee a responsibility in the framework, for example, the Real Estate (Regulations and Development) Act, 2016, prompted sound end-client marketplace. The development in private costs in the greater part of the best eight urban communities of India were seen as low compared to the retail expansion growth.

Published By:

Blue Eyes Intelligence Engineering \& Sciences Publication

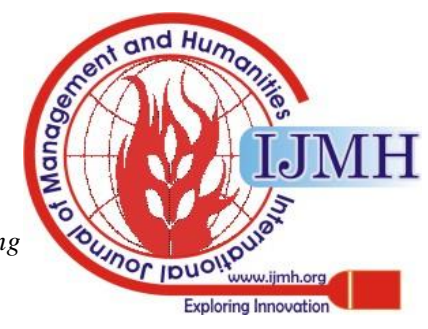




\section{Impact of COVID-19 on Real Estate Industry with Reference to India}

Hungary drives the list with $15.4 \%$ yearly value development, trailed by Luxembourg at $11.4 \%$ and Croatia at $10.4 \%$ in the second and third position separately. Slovakia was positioned at fourth spot with home evaluating rate $9.7 \%$, Latvia-fifth position (9\%), Czech Republic-sixth (8.7\%), China-seventh position (8.5\%), Jersey-eighth $\operatorname{rank}(8.5 \%)$, Mexico-ninth $\operatorname{rank}(8.4 \%)$ and Russia-tenth $\operatorname{rank}(8.1 \%)$.Across 56 nations, the costs rose at a yearly pace of $3.7 \%$ all things considered. It is to be noticed that it is the slowest pace of development for more than 6 years. 91\% of all out assessed nations and regions enrolled static or positive development in the year to September 2019.The COVID-19 pandemic beginning in china has impacted people all over the world. It has halted business cycle, economic activities and its impact can be seen in many industries. The Indian real estate sector which was already struggling due to policy changes, liquidity crisis is now facing another challenge and that is impact of coronavirus on Indian economy and its implication for real estate industry. Indian land division is the second biggest employer after agriculture and the aftermath of this pandemic is going to affect the people working in this sector.

\section{LITERATURE REVIEW}

According to Anarock report (2020) covid-19 impact on Indian real estate In regular occasions, the progressing time frame typically observes an uptick in real estate exercises attributable to celebrations like Ugadi, Gudi Padwa, Akshaya Tritiya and Navaratri when new deals shoot up. Up and coming excursion time for Indian schools starting April till June-end likewise offers time to homebuyers to make buy decisions. Unfortunately, 2020 is by all accounts extraordinary. Nationwide lockdown until mid-April has ended all exercises. As obvious, venture destinations are closed, site visits have halted, and development action has gone to a crushing stop, in the long run affecting deals. Additionally, developer have conceded their new venture dispatches for an obscure period. Other than residential section, commercial segment is additionally not insusceptible to the Covid-19 aftermath. Indicated by JLL (2020) in "COVID-19 global real estate implications. Over the present moment, speculation action may slowdown as valuation challenges and more extensive vulnerability make obstructions to investors' capacity to fittingly cost risk. Despite sufficient liquidity across equity and debts, loan specialists and speculator are staying in a period of value disclosure. Despite changes in feeling and action, the general pattern has been for higher portion allocation to real estate, and see no purpose behind this pattern to turn around over the medium to long haul given the upsides of such investments. FICCI(2020) in "impact of COVID-19 on Indian economy" states year 2019 was a troublesome one for the real estate industry, which keeps on battling with funding emergency amidst issues tormenting the NBFC and banking part. The circumstance has been exacerbated by the monetary log jam bringing about poor demand. There have likewise been basic changes in the business, as an aftermath of occasions like demonetisation and the presentation of the RERA and the GST over the most recent couple of years. The business was planning to recoup from this drawn out stoppage in 2020. The COVID-19 pandemic, be that as it may, can possibly put a few brakes on India's land advertise, given the foreseen drop in demand. The episode of coronavirus has not majorly affected the real estate until this point. In any case, a drawn out effect of the coronavirus might not favourably affect the possibilities for the real estate business.

\section{OBJECTIVE}

A. To study the Indian real estate sector before COVID-19

B. To understands the implication of COVID-19 on Indian real estate

C. To understand the threat and opportunities for homebuyers, builders and workforce in real estate.

D. To draw conclusion.

\section{METHODOLOGY}

This research article is based on data from secondary sources. Reports from various organisations on real estate are used to the data for this article example reports from FICCI, knight frank, WEF and Anarock. Various article published in economic times and other secondary sources are utilised in this article.

\section{RESEARCH RESULT}

India is among the top 10 largest economies of the world. The Indian real estate after facing various challenges in the form of demonetisation, reforms and GST was expected to grow and become stronger than before. If we look at the projections before this pandemic.in 2017 the market size of the industry was USD 120 billion and it was projected to grow to 180 billion in 2020. Further to USD 650 billion in 2025 and to USD 1000 billion till 2030.

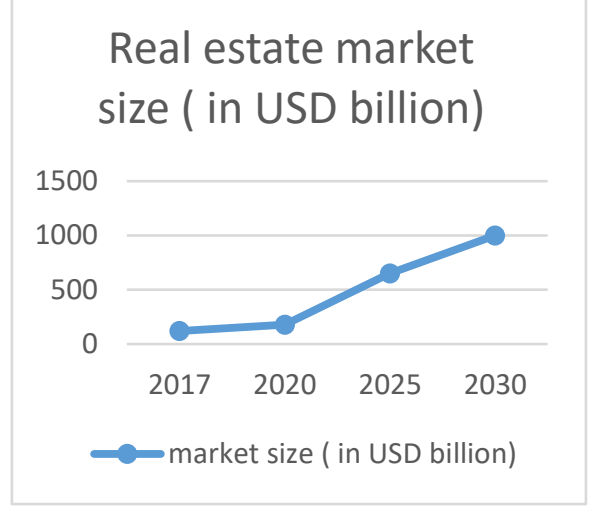

Figure-1: Real Estate Market Size

This industry was contributing 6 percent to GDP of India and was estimated to contribute to 13 percent in 2025. The industry was providing employment to 40 million people in 2013 which increased to 52 million in 2017 and was projected to employ as much as 67 million in 2022, thus an increase of 28.84 percent from 2017 to 2022. However this all seem difficult to achieve now. Post lockdown the construction sector will face a shortage of workers as most of the workers have migrated to their villages and travel restriction will remain in some form or the other.

Published By:

Blue Eyes Intelligence Engineering

\& Sciences Publication

(C) Copyright: All rights reserved.

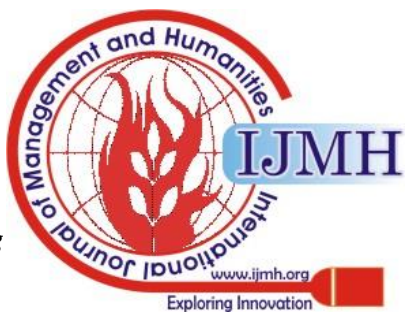


FDI inflow had already slowed down for example the absolute FDI inflow from April- December 2019 to April December 2019 saw a decrease of 7 percent. In the forthcoming quarter it is expected to further decline. Commercial real estate which was showing strong growth in the past years will also be impacted by the recent pandemic. Reduction in GDP growth rate and a world economy recovering from the wounds of COVID-19 will have negative impact on office demand. The supply and net absorption will be considerably lower in 2020 and the forthcoming years. The basis for this prediction found its roots in the aftermath of 2008 crisis. As we would see it, development delays might approach a while for well financed undertakings, while for others, the postponements may even be to the tune of two or three years. Real estate industry is probably going to observe significant disturbances due to development deferrals and financing issues. In addition, this time around festive season what's more, summer vacation period which is the most ideal for new dispatches has been dry for the industry. The second from last quarter of any schedule year is delayed for new dispatches because of the progressing monsoon season and 'shraad' period. Considering that real estate deals are exceptionally subject to physical site visits, connections, conversations and physical documentation, the deals in 2020 may be fundamentally hit because of the current COVID-19 episode in India. Numerous home buyers will consider deferring their choices either to avoid the site visits or in the desires at some cost correction.it is believed that the most influenced fragments of the working populace is the target for affordable housing. These home buyers with constrained salary and absence of telecommute offices may need to confront misfortune of pay or even occupations and may reevaluate their buy choices. With reasonable or affordable lodging units representing around $36 \%$ of the by and large unsold stock over the main 7 urban areas as of Q1 2020, this section was already facing challenges what's more, the present pandemic episode has further declined its situation The mindfulness and acknowledgment for offices and comforts that accompany "Integrated Townships" have upgraded because of the emergency and individuals may begin taking a gander at these townships as the future standard. While a couple of market changes might be noticeable over the business, extends by Grade A developers that fuse top notch, independent biological systems and give sheltered and secure situations would consistently be a favourable purchase for a genuine purchaser even post the COVID-19 pandemic.

However everything is not bleak, every event lays out some challenges but also provide opportunities. The following table try to line out the threats and opportunities presented to buyers, owners and builders.

Table-2: Threats and opportunities to various real estate participation

\begin{tabular}{|c|c|c|c|c|}
\hline Participan & Threat & & Oppor & nity \\
\hline Buyers & $\begin{array}{l}> \\
> \\
>\end{array}$ & $\begin{array}{l}\text { Delayed } \\
\text { delivery } \\
\text { Pay cuts } \\
\text { Threat to jobs } \\
\text { post COVID- } \\
19 \text { may } \\
\text { impact their }\end{array}$ & $\begin{array}{l}> \\
>\end{array}$ & $\begin{array}{l}\text { Reduction in } \\
\text { home loan } \\
\text { interest rate } \\
\text { Exemption of } 3 \\
\text { month in home } \\
\text { loan EMIs } \\
\text { Various }\end{array}$ \\
\hline
\end{tabular}

discount deals by builders

$>$ More time to pay property tax

$>$ Opportunity to bargain

$>$ Force majeure

$>$ Exemption from penalties in delayed delivery

$>$ Possible extension delivery deadlines getting delayed due to suspended construction and labour migration to their hometown.

$>$ Liquidity crisis

$>$ Economic slow down

$>$ Reduced FDI

$>$ Buyers waiting for the prices to fall anticipation

$>$ Bring technology to the rescue example virtual site visits

$>$ Buyers will prefer finished projects

$>$ After the construction activity starts those who did not migrated will be benefitted

$>$ Social security packages announced by government

$>$ Brokers engage in real estate can go for ebrochure, virtual tours and walk through the property which is cheaper preferable and safer in a post COVID-19 world

In assisting homebuyers with combatting the liquidity emergency activated by the COVID-19 actuated lockdown, the Reserve Bank of India (RBI) sliced repo rate by 75 premise focuses in March. This was joined by a discretionary expansion of home advance and different by a quarter of a year. Focal Government's choice to improvement in the following five years gave a new rent of life to the development business.

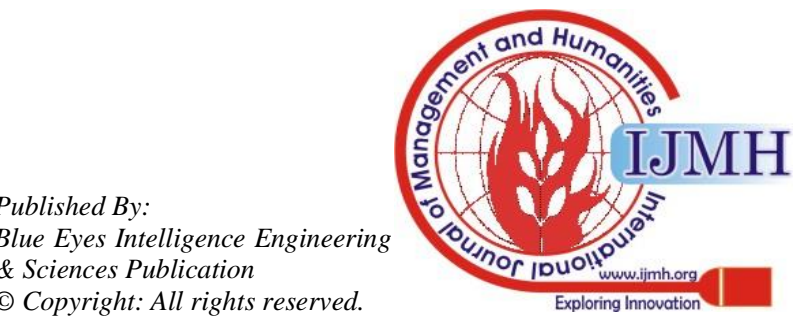




\section{Impact of COVID-19 on Real Estate Industry with Reference to India}

Post the flare-up of Coronavirus, the Securities and Exchange Board of India (SEBI) endorsed brief unwinding of one-month on half-yearly certificate on share transfer and unwinding of three weeks on the quarterly statements of speculator grumblings for Real Estate Investment Trusts (REITs) and Infrastructure Investment Trusts (InvITs).The shutdown of development exercises represented a bigger risk to the money related strength of the engineers, who were yet to defeat from the Non-Banking Financial Companies (NBFC) emergency. The pandemic, be that as it may, may trigger value revision in short to mid-term. If quick to transient impact is thought of, commercial real estate will be hit massively. Be that as it may, in the long term, the business land will be the quickest portion to bob back. Although the Coronavirus emergency may be the purpose behind one of the best monetary lulls everything being equal, it is making a venture open door for the NonResident Indians (NRIs). With the USA and Europe getting seriously hit by the pandemic, the venture openings have fallen radically. This has raised the stakes for Indian markets as ex-taps are relied upon to progressively concentrate on interests in the real estate back home. The rules gave by the National Association of Realtors likewise propose exchange advertising open doors for real estate agents, including video visits and other comparative strategies.

\section{CONCLUSION}

The industry needs to prepare itself for a much more dreadful effect than recently suspected. With the danger of disease influencing human lives, the R.E part is now observing a decrease in property visits and purchaser intrigue. Be that as it may, the world has confronted comparative flare-ups, for example, SARS infection, bird flu and so forth in the past as well and has effectively recuperated. Each cataclysm is a chance to scale new statures. R.E. ventures must discover inspiration in the situation and advantage by expanding creation and indigenous development. The authorities would do well to stop further expansion of the infection and handhold the business in the hours of emergency. Pause and Watch is certainly not the correct procedure for the real estate industry. Taking cognisance of the way that buyer needs and opinions are of most extreme significance for an industry to flourish, the organizations should obviously approach with some shrewd answers to gather shopper intrigue.

\section{REFERENCES}

1. FICCI, "impact of COVID-19 on indian economy," 2020.

2. anarock, "COVID-19 impact on indian real estate," 2020.

3. JLL, "COVID-19 global real estate implications," 2020.

4. www.bloombergquint.com.

5. corporate.cyrilamarchandblogs.com.

6. www.mckinsey.com.

7. www2.deloitte.com.

\section{AUTHORS PROFILE}

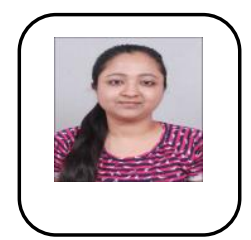

Jyoti Bhoj, The author is a research scholar in university of Rajasthan, Jaipur. She has submitted her thesis in December 2019. Her topic of research is "a study of regret aversion and false reference points in residential real estate with reference to Delhi- NCR" Her research focus on regret aversion and false reference points taken by investors in residential rea estate. It study the impact of gender, education, marital status and income on regret aversion. This study also analysis the difference in regret aversion when house is purchased for investment from when it is purchased for selfresidence. She has keen interest in research and has written various research articles.

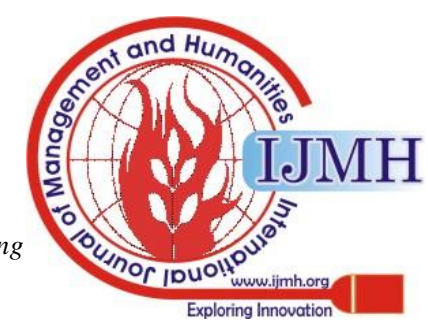

